\title{
A quick screening to assess the phytoextraction potential of cadmium and copper in Quercus pubescens plantlets
}

\author{
Patrick Di Santo ${ }^{(1)}$, \\ Claudia Cocozza (2), \\ Roberto Tognetti ${ }^{(3-4)}$, \\ Giuseppe Palumbo (1), \\ Erika Di lorio ${ }^{(1)}$, \\ Bruno Paura ${ }^{(1)}$
}

\begin{abstract}
The relevance of the environmental pollution by heavy metals warrants the necessity to develop and assess more efficient plant-based technologies. This study was conducted to evaluate a quick screening approach in order to investigate the cadmium $(\mathrm{Cd})$ and copper $(\mathrm{Cu})$ phytoextraction potential of Quercus pubescens in a micro-propagation system. Increasing concentrations of $\mathrm{Cd}(0$, $5,50$, and $250 \mu \mathrm{M})$ and $\mathrm{Cu}(0,5,50,250$ and $500 \mu \mathrm{M})$ were separately applied to evaluate the effect of metals on their absorption and accumulation in downy oak plants. At high concentrations, $\mathrm{Cd}$ and $\mathrm{Cu}$ significantly reduced the dry biomass of shoots and roots and the plant tolerance index. Cd was toxic at increasing concentrations, inducing higher reduction of shoot dry mass than roots, whereas $\mathrm{Cu}$ increased dry mass at $5 \mu \mathrm{M}$. This study represents the first attempt to assess $\mathrm{Cd}$ and $\mathrm{Cu}$ uptake in $Q$. pubescens under in vitro conditions. The in vitro screening potential is meanly related to the following purposes: (i) proper selection of plant materials resilient to excess metals in the growth substrate; (ii) efficient removal of metals by the selected tree species; (iii) minor interference with the growth of plants accumulating metals in their tissues; (iv) rapid provision of plant materials for tree breeding programs.
\end{abstract}

\section{Keywords: Heavy Metals, Phytoremediation, Downy Oak, Micropropagation}

\section{Introduction}

The accumulation of heavy metals in soils and water poses a risk to the environmental and human health (Khan et al. 2008). Considerable progress in phytoremediation has been made with metals using hydroponically-cultured plants transplanted in metal-polluted sites, where plants eventually absorb and concentrate metals in their roots and shoots (Tognetti et al. 2013). Phytoremediation is a well-recognized, environmental-friendly strategy to control pollution by heavy metals (Ali et al. 2013). Phytoremediation includes strategies like phytoextraction and phytostabilization, which are defined by the preferential accumulation of pollutants by plants in their aboveand below-ground organs, respectively (Pulford \& Watson 2003, Pilon-Smits 2005).
Among heavy metals, cadmium (Cd) is one of the most threatening due to its toxicity for the environment, crops and therefore for consumers (Perfus-Barbeoch et al. 2002). Cadmium has a strong carcinogenic potential (García-Esquinas et al. 2014) and is also very toxic for plants, affecting water and nutrient uptake, as well as their photosynthetic efficiency (Pietrini et al. 2010). Copper (Cu) is a microelement essential for plant growth, though it may become potentially toxic at elevated levels, particularly as a result of agricultural practices, and industrial or municipal waste disposal on land (Ali et al. 2004).

The plant capacity to tolerate metals can rely on a variety of resistance and tolerance mechanisms (Pietrini et al. 2010, Wang et al. 2014). Plants have evolved $\square$ (1) Dipartimento Agricoltura, Ambiente e Alimenti, Università degli Studi del Molise, I86100 Campobasso (Italy); (2) Istituto per la Protezione Sostenibile delle Piante (IPSP), Consiglio Nazionale delle Ricerche (CNR), v. Madonna del Piano 10, I-50019 Firenze (Italy); (3) Dipartimento di Bioscienze e Territorio, Università degli Studi del Molise, I-86090 Pesche (Italy); (4) The EFI Project Centre on Mountain Forests (MOUNTFOR), Edmund Mach Foundation, I-38010 San Michele all'Adige (Italy)

@ Claudia Cocozza (claudia.cocozza@ipsp.cnr.it)

Received: Jan 29, 2016 - Accepted: Aug 02, 2016

Citation: Di Santo P, Cocozza C, Tognetti R, Palumbo G, Di lorio E, Paura B (2016). A quick screening to assess the phytoextraction potential of cadmium and copper in Quercus pubescens plantlets. iForest 10: 93-98. - doi: 10.3832/ifor1999-009 [online 2016-10-13]

Communicated by: Tamir Klein avoidance strategies or exclusion processes, which reduce metal accumulation in cells, as well as mechanisms of surviving despite the accumulation of large amounts of metals (Rascio \& Navari-Izzo 2011). Phytoextraction can be achieved through hyperaccumulator plants, which exhibit the capability to take up from soil large quantities of heavy metals, which are then translocated to the epigeous parts (Wong 2003, Yang et al. 2004). However, these plant species have low biomass accumulation and removal potential in absolute terms. Therefore, selection and/or breeding of suitable plant genotypes based on biomass production, accumulation potential, root traits, growth rate, environmental suitability and metal resilience are required for their use in the remediation of heavy metal contamination (Wang et al. 2014). In the last ten years, research was focused on highly productive crop plants, such as crops, maize, sunflower, rice (Komarek et al. 2007, Murakami \& Ae 2009), as well as on short rotation forest trees, i.e., willow and poplar (Fernàndez-Martínez et al. 2014, Baldantoni et al. 2014). Phytoextraction carried out with the use of other woody plants can be extremely interesting for the restoration of contaminated sites, where environmental conditions are unsuitable for growing energy plants, as well as for their longer reproductive cycles (Paoletti \& Günthardt-Goerg 2006, Cocozza et al. 2012).

Biotechnologies are currently available for better understanding the process of heavy metal uptake by trees and exploring 
their potential and exploitability in the remediation improvement (Capuana 2011). In vitro cultures provide several advantages when the plant cell tolerance to toxic elements is to be examined in experimental studies (Golan-Goldhirsh et al. 2004, Doran 2009). In this sense, in vitro screening is a preliminary tool for testing woody plant materials, reducing the growth period and the treatment duration, as well as the space needed for the experiments (Confalonieri et al. 2003, Di Lonardo et al. 2011). We anticipate that in vitro cultures represent a valuable research tool for phytoremediation of contaminated substrates and provide the required axenic conditions for screening the potential of a plant species to tolerate and accumulate heavy metals
Fig. 1 - Plantlets grown in micro-propagation (five glass jars per treatment containing five rooted shoots each) after 4 weeks of Cu treatment.
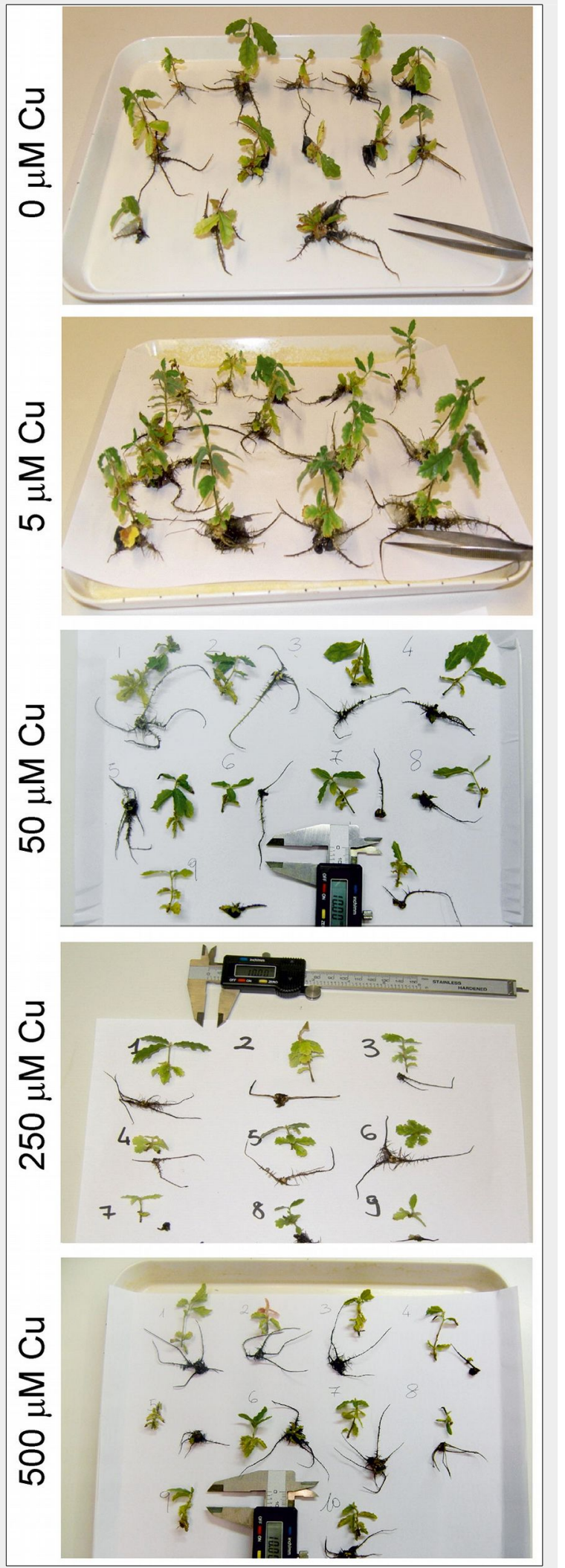

(Di Lonardo et al. 2011, lori et al. 2012). Particularly, Di Lonardo et al. (2011) set up a test for the quick selection and assessment of poplar clones aimed to characterize the most suitable material for phytoremediation. This approach helps the quick evaluation of the most promising candidates (plant species and their clones) for further trials on polluted soils. Poplar has been used as model species in this screening test (Di Lonardo et al. 2011). However, the efficacy of this approach to test other woody plant species, not traditionally used for phytoremediation purposes, is unknown.

Quercus species are long-living forest trees whose micropropagation in vitro is sometimes troublesome. Nonetheless, preliminary results on the tolerance of downy oak (Quercus pubescens Willd.) seedlings to metal-polluted substrates has proven this species as an interesting candidate for the phytostabilization of contaminated sites, particularly in marginal areas (Cocozza et al. 2012). In this context, the aims of the present study were to: (i) assess growth perfomances of micropropagated plantlets of downy oak (Q. pubescens Willd.) cultivated on $\mathrm{Cd}$ and $\mathrm{Cu}$ artificially-contaminated substrate; (ii) define their uptake potential and metal bioaccumulation in roots and shoots at increasing concentrations of metals in the substrate.

\section{Materials and methods}

\section{Plant material and in vitro growth condition}

Plant material was obtained from cut buds of two years old downy oak seedlings. The buds were washed with tap water and their surface sterilized by $\mathrm{Cl} 2 \%$. In vitro proliferating microshoots of $Q$. pubescens were subcultured on woody plant medium (WPM - Lloyd \& McCown 1980), added with $2 \%$ sucrose, $0.5 \mathrm{mg} \mathrm{l}^{-1} \mathrm{BA}$ at $\mathrm{pH}$ 5.6, in baby food-glass jars sterilized by autoclaving at $121{ }^{\circ} \mathrm{C}$ and $108 \mathrm{kPa}$ for 20 $\mathrm{min}$. The aseptic cultures were incubated in a growth chamber at $23 \pm 1{ }^{\circ} \mathrm{C}$ with a 16 -h photoperiod $\left(40 \mu \mathrm{E} \mathrm{m}^{-2} \mathrm{~s}^{-1}\right)$ and routinely subcultured every 4 weeks. To promote rooting, microshoots were placed in contact with $20 \mathrm{mg} \mathrm{l}^{-1}$ IBA half strength WPM medium for $24 \mathrm{~h}$ in growth chamber. Finally, microshoots were transferred to phytohormone-free WPM medium for four weeks, added with $1 \mathrm{~g} \mathrm{l}^{-1}$ charcoal to remove hormone carry-over effect and enhance shoot and root elongation. At this point of the experiment, the lack of sucrose in the medium induced well-developed rooted plants to autotrophic phase; gas exchange was improved with autotrophic micro-propagation (Fig. 1).

\section{Metal treatment}

Well-developed rooted plantlets were transferred to phytohormone-free WPM medium containing different metal concentrations: $0,5,50,250 \mu \mathrm{M} \mathrm{Cd}$ and $0,5,50$, 250 and $500 \mu \mathrm{M} \mathrm{Cu}$, supplied as $\mathrm{CdSO}_{4}$ and 
$\mathrm{CuSO}_{4}$, respectively. Twenty plants per concentration (four glass jars per treatment, containing five rooted shoots each) were used in the experiment. Other 20 plants were dried at $70{ }^{\circ} \mathrm{C}$ for $24 \mathrm{~h}$ and then weighed to estimate a mean value of the dry biomass at the beginning of the experiment.

\section{Determination of metal content}

After 15 days of treatment, plantlets were gently removed from the medium and roots were carefully washed. Roots were desorbed with $10 \mathrm{mM} \mathrm{CaCl}$ solution for 10 min to remove the adhering metals from the cell walls and determine the intracellular fraction of heavy metals. $\mathrm{CaCl}_{2}$ was used as extractant to avoid plasma membrane alteration and metal displacement. Plantlets were separated into shoots and roots, dried at $70^{\circ} \mathrm{C}$ for $24 \mathrm{~h}$ and then weighed. The dry biomass production (dry biomass at the end of the experiment minus that previously estimated at the beginning of the experiment) was used as a measurement of the metal toxic effects (Baker \& Walker 1989). The tolerance index (Ti) was calculated as the ratio between the dry mass of plants (shoots and roots) grown in the solution with metal and that of plants grown in the control solution (Zacchini et al. 2009).

Roots and shoots of plantlets exposed to $\mathrm{CdSO}_{4}$ and $\mathrm{CuSO}_{4}$ were ground in a stainless steel plant mill and mineralized in $4 \mathrm{ml}$ concentrated $\mathrm{HNO}_{3}$ and $1 \mathrm{ml}$ concentrated $\mathrm{HClO}_{4}$ at $225^{\circ} \mathrm{C}$ using an automated heating block (Digester DK $42 / 26^{\circledR}$, Velp Scientifica, Milano, Italy). After digestion, $\mathrm{Cu}$ and $\mathrm{Cd}$ were determined by inductively coupled plasma optical emission spectroscopy (ICP-
OES, Varian Vista-MPX). The procedure was validated with reference materials of poplar leaves (GBW 07604 - limit of detection 1 $\left.\mu \mathrm{g} \mathrm{I}^{-1}\right)$. Metal contents were calculated as the product between mean dry biomass of plantlets ( $n=5$ seedlings) and mean metal concentration in each plant.

\section{Statistical analysis}

Treatments were performed in quintuplicate and repeated at least in four independent experiments. Normal distribution of the data was tested using the KolmogorovSmirnov test; since no significant departures from normality were found, parametric comparison methods were used (Razali 2011). Data were averaged on a plant basis and the individual means were used for the analysis. The effects of metal treatment on the development traits and metal uptake were tested using the repeated-measures analysis of variance (ANOVA). To assess the differences between treatments for the measured parameters, a post hoc comparison of means was performed using the least significant difference (LSD) test or the Tukey's test with $a=0.05$. Statistical analysis was performed using the software packages STATISTICA ${ }^{\circledast}$ (StafSoft Inc., Tulsa, OK, USA) and SPSS ${ }^{\circledast}$ ver. 16.0 (SPSS Inc., Chicago, IL, USA) for Windows ${ }^{\mathrm{TM}}$.

\section{Results and discussion}

The micro-propagation system highlighted that high concentrations of $\mathrm{Cd}$ and $\mathrm{Cu}$ were toxic for downy oak. The study clearly illustrated the detrimental effects of excess metal on plant growth, as shown by the smaller dry biomass accumulation in shoots and roots of Cd-treated plants compared with non-contaminated plantlets
(Fig. 2). As expected, Cd-treated plantlets showed a decreased shoot biomass at increasing concentration of the contaminant, while the biomass of roots was negatively affected in a similar way by all Cd treatments (Fig. 2). Regarding the $\mathrm{Cu}$ treatments, the dry biomass of shoots and roots of plantlets was significantly higher at $5 \mu \mathrm{M}$ compared with other treatments and control conditions, suggesting a positive effect of low $\mathrm{Cu}$ concentration on plant growth (Kunjam et al. 2015). However, copper became highly toxic at higher concentrations (Fig. 2). For both metals, the accumulations in seedlings, shoot and root tissues increased with increasing metal contamination (Fig. 3). The accumulation of $\mathrm{Cd}$ and $\mathrm{Cu}$ was significantly higher at the highest contamination (50 and $250 \mu \mathrm{M}$ Cd treatment; 250 and $500 \mu \mathrm{M}$ Cu treatment - Fig. 3). Thus, the reduced growth of micro-propagated downy oak plantlets was likely due to the high metal accumulation in the roots and to a moderate metal translocation to the shoots.

The tolerance index in shoots of $\mathrm{Cd}$ treated plants was higher at low $(5 \mu \mathrm{M})$ than at high (50 and $250 \mu \mathrm{M})$ metal concentration, while no significant differences in tolerance index of roots were observed between $\mathrm{Cd}$ treatments (Fig. 4). The tolerance index of shoots in Cu-treated plants was higher at $5 \mu \mathrm{M}$ and $250 \mu \mathrm{M}$ compared to other concentrations, while the value in roots was higher at low than at high metal concentration (Fig. 4). However, the low tolerance index at increasing contamination in both metal treatments corresponded to a reduction in plant growth. The high concentration of non-essential (Cd) and essential (Cu) metals could have negatively

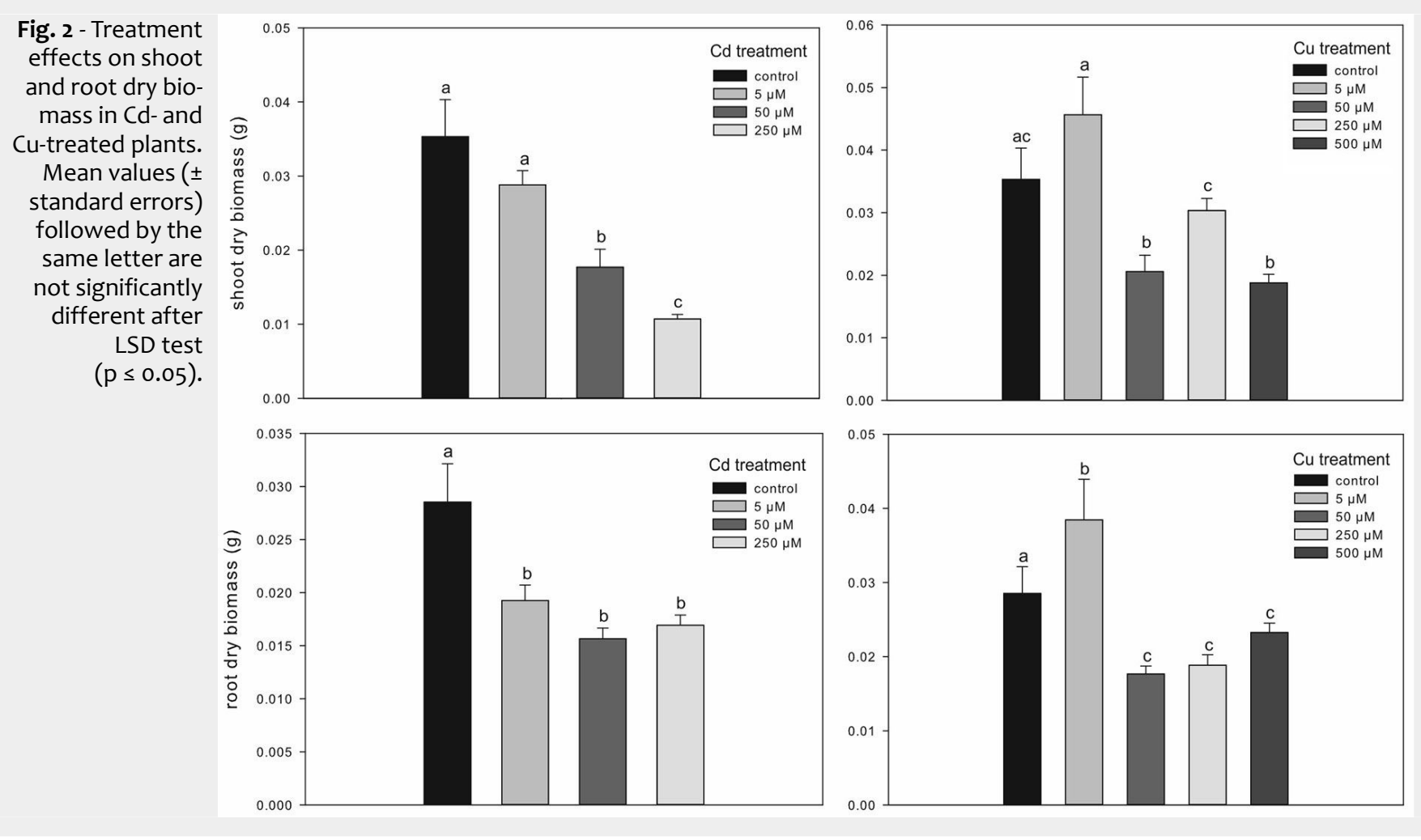



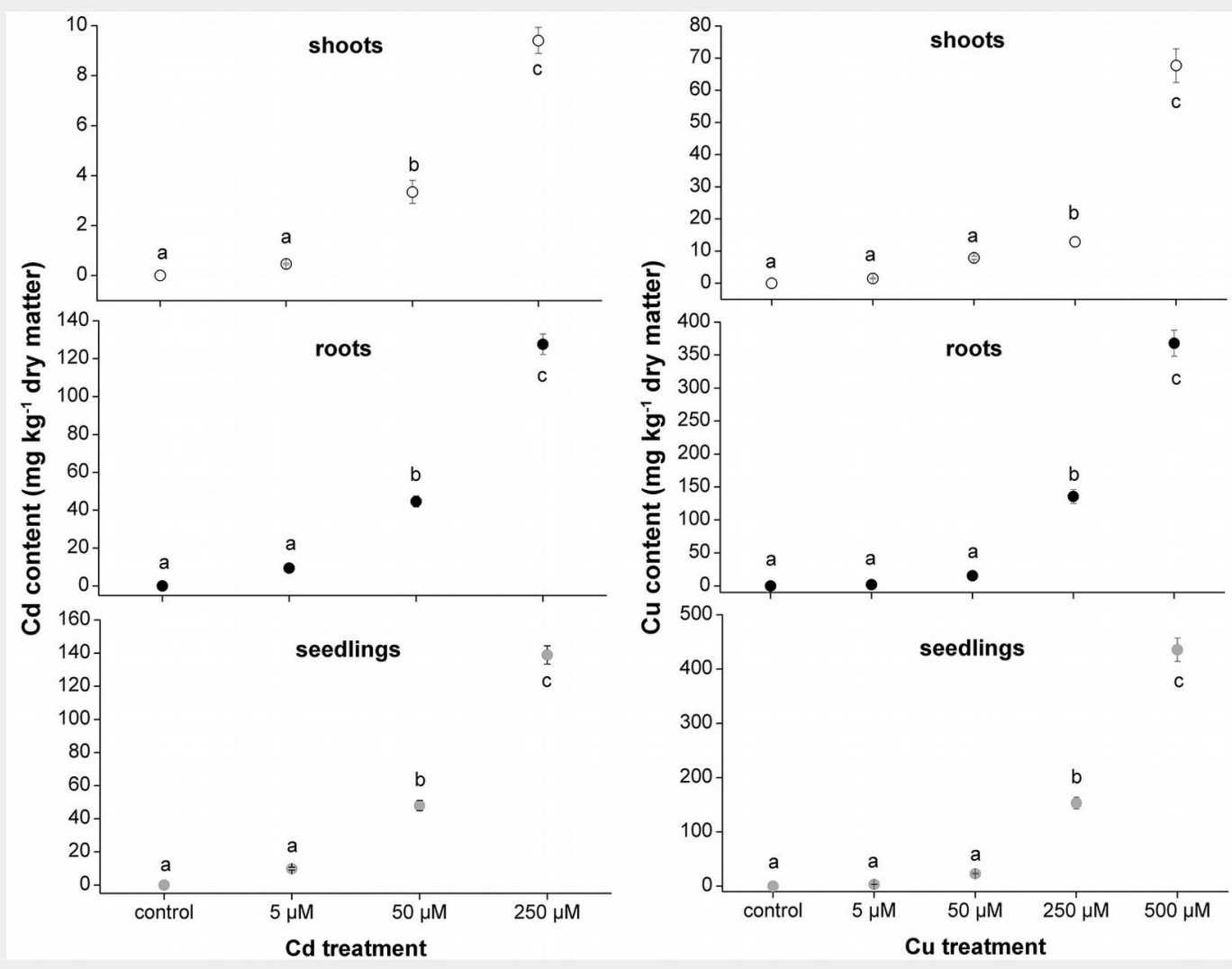

Fig. 3 - Cadmium and $\mathrm{Cu}$ contents (milligram per kilogram of dry matter) in shoots, roots and whole seedlings of $\mathrm{Cd}$ - and $\mathrm{Cu}$ treated plants. Mean values ( \pm standard errors) followed by the same letter are not significantly different after LSD test $(p \leq 0.05)$.
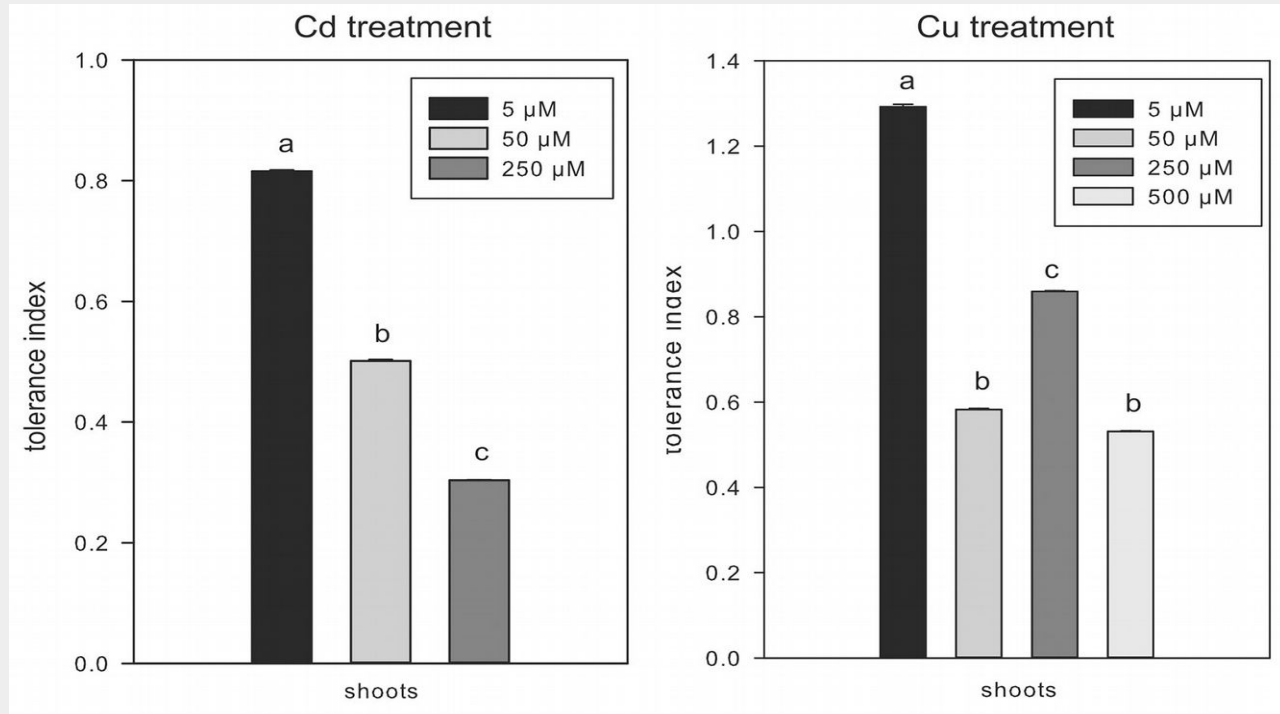

Fig. 4 - Tolerance index in shoots and roots of $\mathrm{Cd}$ - and $\mathrm{Cu}$-treated plants. Mean values ( \pm standard errors) followed by the same letter are not significantly different after LSD test $(p \leq 0.05)$.
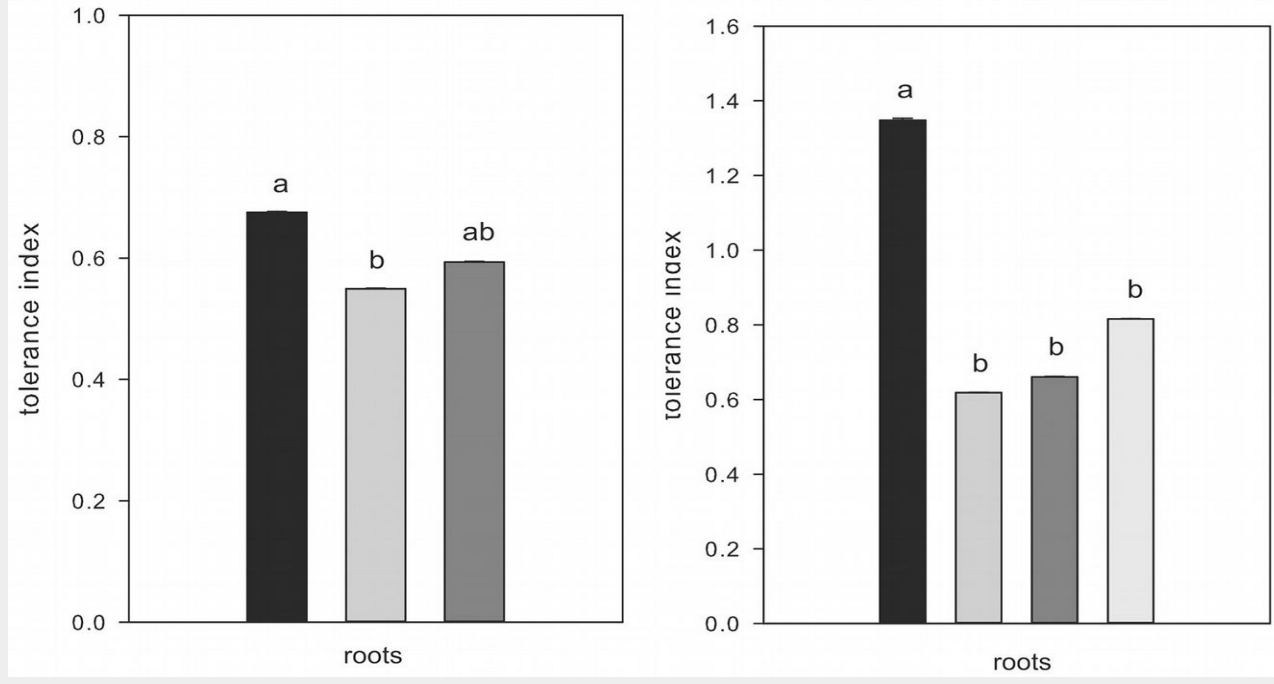
affected the photosynthetic machinery in these woody plants ( $\mathrm{Di}$ Lonardo et al. 2011). Nevertheless, the potential for metal accumulation at the root level might have been affected by the release into the rizosphere of chelating agents with high affinity for metals, thus favoring metal sequestration (Schat et al. 2002, Shah \& Nongkynrih 2007).

The in vitro culture approach adopted in this study has proven to be effective to test whether downy oak could be further assessed for resilience to metal contamination over longer experimental periods and/ or under in situ conditions. Indeed, the metal concentrations used in our micropropagation conditions were very high, in particular when considering that downy oak is not widely recognized as an efficient forest species for decontamination purposes. Nonetheless, its potential $\mathrm{Cd}$ accumulation is high, as detected in pot experiments (Cocozza et al. 2012), and this might advocate its use in ecological restoration of polluted sites in marginal areas. Our results provide a preliminary evidence of the remediation potential of downy oak in vitro, although they should not be extrapolated to predict the effects of heavy metals on the growth of mature oak trees. The in vitro approach offered a stable growth medium, where plants freely absorbed metals from the substrate and translocate them to shoots, with minor interactions with surrounding conditions during the phytoextraction process. Common-garden investigations and provenance trials are planned in this species to test whether geographic variations of adaptive traits should be considered in the selection of material to be used in the restoration of contaminated sites in marginal areas of Italy. The in vitro screening carried out in this study allowed for: (i) testing the tolerance of plant materials to high-concentration metals in a short period of time; (ii) providing a suitable environment for the study of plant processes in response to metal treatments. This approach can be further improved towards appropriate breeding strategies and field trials.

\section{References}

Ali H, Khan E, Sajad MA (2013). Phytoremediation of heavy metals - Concepts and applications. Chemosphere 91: 869-881. - doi: 10.1016/j. chemosphere.2013.01.075

Ali NA, Bernal MP, Ater M (2004). Tolerance and bioaccumulation of cadmium by Phragmites australis grown in the presence of elevated concentrations of cadmium, copper, and zinc. Aquatic Botany 80: 163-176. - doi: 10.1016/j.aqua bot.2004.08.008

Baker AJM, Walker PL (1989). Physiological responses of plants to heavy metals and the quantification of tolerance and toxicity. Chemical Speciation and Bioavailability 1: 7-17. [online] URL: http://www.tandfonline.com/doi/abs/10.10 80/09542299.1989.11083102

Baldantoni D, Cicatelli A, Bellino A, Castiglione S (2014). Different behaviours in phytoremedia- tion capacity of two heavy metal tolerant poplar clones in relation to iron and other trace elements. Journal of Environmental Management 146: 94-99. - doi: 10.1016/j.jenvman.2014.07.045 Capuana M (2011). Heavy metals and woody plants - biotechnologies for phytoremediation. iForest 4: 7-15. - doi: 10.3832/iforo555-004

Cocozza C, Palumbo G, Colombo C, Tognetti R (2012). Ecophysiological characteristics and cadmium accumulation in Downy Oak (Quercus pubescens Willd.). Forest@ - Rivista di Selvicoltura ed Ecologia Forestale 9 (5): 217-226. [in Italian with English abstract] - doi: 10.3832/efor 0700-009

Confalonieri M, Balestrazzi A, Bisoffi S, Carbonera D (2003). In vitro culture and genetic engineering of Populus spp.: synergy for forest tree improvement. Plant Cell Tissue and Organ Culture 72: 109-138. - doi: 10.1023/A:1022265504775 Di Lonardo S, Capuana M, Arnetoli M, Gabbrielli $\mathrm{R}$, Gonnelli C (2011). Exploring the metal phytoremediation potential of three Populus alba L. clones using an in vitro screening. Environmental Science and Pollution Research 18: 829o. - doi: 10.1007/s11356-010-0354-7

Doran PM (2009). Application of plant tissue cultures in phytoremediation research: incentives and limitations. Biotechnology and Bioengineering 103: 60-76. - doi: 10.1002/bit.22280

Fernàndez-Martínez J, Zacchini M, FernándezMarín B, García-Plazaola JC, Fleck I (2014). Gasexchange, photo- and antioxidant protection, and metalaccumulation in $\mathrm{I}-214$ and Eridano Populus sp. clones subjected toelevated zinc concentrations. Environmental and Experimental Botany 107: 144-153. - doi: 10.1016/j.envexpbot. 2014.06.004

García-Esquinas E, Pollan M, Tellez-Plaza M, Francesconi KA, Goessler W, Guallar E, Umans JG, Yeh J, Best LG, Navas-Acien A (2014). Cadmium exposure and cancer mortality in a prospective cohort: the Strong Heart Study. Environmental Health Perspectives 122: 363-370. [online] URL: http://www.ncbi.nlm.nih.gov/pmc/articles/PMC 3984227/

Golan-Goldhirsh A, Barazani O, Nepovim A, Soudek P, Smrcek S, Dufkova L, Krenkova S, Yrjala K, Schröder P, Vanek T (2004). Plant response to heavy metals and organic pollutants in cell culture and at whole plant level. Journal of Soils and Sediments 4: 133-140. - doi: 10.1007/ BF02991058

Iori V, Pietrini F, Zacchini M (2012). Assessment of ibuprofen tolerance and removal capability in Populus nigra L. by in vitro culture. Journal of Hazardous Materials 229-230: 217-223. - doi: 10.1016/j.jhazmat.2012.05.097

Khan S, Cao Q, Zheng YM, Huang YZ, Zhu YG (2008). Health risks of heavy metals in contaminated soils and food crops irrigated with wastewater in Beijing, China. Environmental Pollution 152: 686-692. - doi: 10.1016/j.envpol.20 07.06.056

Komarek M, Tlustos P, Szakova J, Chrastny V, Ettler V (2007). The use of maize and poplar in chelant-enhanced phytoextraction of lead from contaminated agricultural soils. Chemosphere 67: 640-651. - doi: 10.1016/j.chemosphere.2006. 11.010

Kunjam M, Govada H, Mididoddi N, Kota RSLN (2015). Studies on selected heavy metals on seed germination and plant growth in pea plant (Pisum sativum) grown in solid medium. Journal of Pharmacognosy and Phytochemistry 3 (5): 85-87. [online] URL: http://www.phyto journal.com/vol3Issue5/Issue jan 2015/33.1.pdf Lloyd G, McCown BH (1980). Commercially feasible micropropagation of mountain laurel Kalmia latifolia by use of shoot-tip culture. International Plant Propagation Society 30: 421-427.

Murakami M, Ae N (2009). Potential for phytoextraction of copper, lead, and zinc by rice (Oryza sativa L.), soybean (Glycine max [L.] Merr.), and maize (Zea mays L.) Journal of Hazardous Materials 162: 1185-1192. - doi: 10.1016/j. jhazmat.2008.06.003

Paoletti E, Günthardt-Goerg MS (2006). Growth responses and element content of Quercus pubescens seedlings under acidic and heavy metal contamination. Forest Snow and Landscape Research 3: 323-337. [online] URL: http://www.issw.ch/fe/walddynamik/projekte/v on_zelle_zu_baum/80_3_02_Paoletti.pdf

Perfus-Barbeoch L, Leonhardt N, Vavasseur A, Forestier C (2002). Heavy metal toxicity: cadmium permeates through calcium channels and disturbs the plant water status. Plant Journal 32: 539-548. - doi: 10.1046/j.1365-313X.2002.014 42.x

Pietrini F, Zacchini M, lori V, Pietrosanti L, Bianconi D, Massacci A (2010). Screening of poplar for clones for cadmium phytoremediation using photosynthesis, biomass and cadmium content analyses. International Journal of Phytoremediation 12: 105-120. - doi: 10.1080/152265 10902767163

Pilon-Smits E (2005). Phytoremediation. Annual Review of Plant Biology 56: 15-39. - doi: 10.1146/ annurev.arplant.56.032604.144214

Pulford ID, Watson C (2003). Phytoremediation of heavy metal-contaminated land by trees - A review. Environment International 29: 529-540. - doi: 10.1016/S0160-4120(02)00152-6

Rascio N, Navari-Izzo F (2011). Heavy metal hyperaccumulating plants: how and why do they do it? And what makes them so interesting? Plant Science 180: 169-181. - doi: 10.1016/j.plant sci.2010.08.016

Razali NM (2011). Power comparison of ShapiroWilk, Kolmogorov-Smirnov, lillefors and Anderson-Darling tests. Journal of Statistical Modeling and Analytic 2: 21-33. [online] URL: http:// s3.amazonaws.com/academia.edu.documents/ 41431616/

Schat H, Llugany M, Vooijs R, Hartley-Whitaker J, Bleeker PM (2002). The role of phytochelatins in constitutive and adaptive heavy metal tolerances in hyperaccumulator and non-hyperaccumulator metallophytes. Journal of Experimental Botany 53: 1-12. - doi: 10.1093/jxb/erf107 Shah K, Nongkynrih J (2007). Metal hyperaccumulation and bioremediation. Biologia Plantarum 51: 618-634. - doi: 10.1007/s10535-007-01345

Tognetti R, Cocozza C, Marchetti M (2013). Shaping the multifunctional tree: the use of Salicaceae in environmental restoration. iForest 6: 37-47. - doi: 10.3832/iforog20-006

Wang S, Shi X, Sun H, Chen Y, Pan H, Yang X, Rafiq T (2014). Variations in metal tolerance and accumulation in three hydroponically cultivated varieties of Salix integra treated with 
lead. PLoS ONE 9 (9): e108568. - doi: 10.1371/ journal.pone. 0108568

Wong MH (2003). Ecological restoration of mine degraded soils, with emphasis on metal contaminated soils. Chemosphere 50: 775-780. doi: 10.1016/S0045-6535(02)00232-1
Yang XE, Long XX, Ye HB, He ZL, Calvert DV, Stoffella PJ (2004). Cadmium tolerance and hyperaccumulation in a new Zn-hyperaccumulating plant species (Sedum alfredii Hance). Plant and Soil 259: 181-189. - doi: 10.1023/B:PLSO.000002 0956.24027.f2
Zacchini M, Pietrini F, Scarascia Mugnozza G, Iori V, Pietrosanti L, Massacci A (2009). Metal tolerance, accumulation and translocation in poplar and willow clones treated with cadmium in hydroponics. Water, Air and Soil Pollution 197: 23-34. - doi: 10.1007/s11270-008-9788-7 